\title{
Efek Kecemasan terhadap Peningkatan Tekanan Darah Penderita Pre OP ORIF
}

\author{
The Effect Anxiety to Increased Blood Pressure in Patients with Pre Op ORIF
}

\author{
Moh Alimansur*, Septinulalin Dwi Cahyaningrum \\ Dosen Akper Dharma Husada Kediri \\ Email: ali.mansur75@yahoo.co.id
}

\begin{abstract}
ORIF surgery is a difficult experience for nearly all patients because ORIF surgery can affect pain, the chances of disabled and dependent on others. Often the patient shows excessive attitude with anxiety they experienced related to all kinds of surgical procedures, excessive attitude of the patient in the form of anxiety is most likely to affect blood pressure. This research aims to know the relationship of the level of anxiety with increased blood pressure patients pre op ORIF. Methods the study was Correlation. As for the technique used is the purposive sampling with the sample as much as 6 respondents. Measuring instrument of data collection using a modification of the HARS questionnaire and tensimeter mercury. The research results obtained there is a relationship between anxiety level of blood pressure in patients with pre op ORIF. With evidence of the 6 respondents in the light level of anxiety (33.3\%) have an average of $125 \mathrm{mmHg}$ Sistole blood pressure and $85 \mathrm{mmHg}$ Diastole, the anxiety of being (16.7\%) had an average blood pressure of $140 \mathrm{mmHg}$ Sistole Diastole and $90 \mathrm{mmHg}$ and anxiety reaction flask 50.0\%) weight (having blood pressure $160 \mathrm{mmHg}$ Sistole Diastole and 93,3 $\mathrm{mmHg}$.The conclusions of this research is that the level of anxiety affect blood pressure, the higher the score, the more anxiety increase Sistole Diastole and blood pressure. Therefore before operating actions done ORIF should give health workers counseling about surgical procedures to patients to reduce anxiety so it does not raise blood pressure.
\end{abstract}

Key Words: Anxiety, Blood Pressure, Pre Op ORIF

\section{Pendahuluan}

Kecelakaan lalu lintas di Indonesia oleh Badan Kesehatan Dunia World Health Organization (WHO) dinilai menjadi pembunuh terbesar ketiga, di bawah penyakit jantung koroner dan tuberculosis/TBC (Badan Intelijen Negara RI, 2013). Selain kematian, kecelakaan dapat menimbulkan dampak lain, yaitu fraktur yang dapat menjadikan kecacatan. Delapan juta orang mengalami fraktur dengan jenis fraktur yang berbeda dan penyebab yang berbeda. Hasil survey tim Depkes RI ini didapatkan $25 \%$ penderita fraktur mengalami kematian, $45 \%$ mengalami kecacatan fisik, $15 \%$ mengalami stress psikologis karena cemas bahkan depresi dan, 10\% mengalami kesembuhan dengan baik (Depkes RI, 2009).

Di RSUD Gambiran Kota Kediri angka kejadian kecelakaan yang mengalami fraktur pada tahun 2011 yang fraktur terbuka (open fracture) $28,9 \%$ dan fraktur tertutup (close fracture) $71 \%$, sedangkan pada tahun 2012 akhir bulan Oktober yang mengalami fraktur terbuka (open fracture) 30,7\% dan fraktur tertutup (close fracture) 69,2\% (Nurianah, 2013).

Oleh karena itu butuh penanganan yang tepat untuk menanganinya, yaitu bisa berupa konservatif ataupun operasi. Salah satu prosedur pembedahan yang sering dilakukan adalah reduksi terbuka dengan fiksasi internal / Open Reduction and Internal Fixation (ORIF), sasaran pembedahan digunakan untuk 
memperbaiki fungsi dengan mengembalikan gerakan dan stabilitas, dimana didalamnya terdapat banyak prosedur yang harus dilaksanakan. Hal ini menyebabkan kecemasan pada masa sebelum operasi ORIF (pre op ORIF), kecemasan ini merupakan hal yang wajar (Muttaqin, 2008). Dari hasil penelitian menunjukkan bahwa sebanyak 46,7\% penderita mengalami kecemasan ringan, $51,1 \%$ mengalami kecemasan sedang, dan kecemasan berat $2,2 \%$ sebelum menjalani operasi ORIF (Arifah dan Trise, 2012). Beberapa orang kadang tidak mampu mengontrol kecemasan yang dihadapi, sehingga bisa terjadi perubahan fisiologis terhadap sistem tubuh. Hal ini akan berakibat buruk, karena kecemasan dapat mempengaruhi stimulasi sistem saraf simpatis, yang meningkatkan frekuensi darah, curah jantung dan tahanan vaskular perifer, selain itu memacu jantung berdenyut lebih cepat serta lebih kuat, sehingga tekanan darah akan meningkat. Dan apabila tidak segera diatasi dapat menyebabkan pendarahan baik pada saat pembedahan ataupun post op ORIF. Intervensi keperawatan yang tepat diperlukan untuk mempersiapkan pasien baik secara fisik maupun psikis sebelum dilakukan operasi ORIF (Kozier, 2009; Riyadi dan Purwanto, 2009).

Dalam menghadapi kecemasan, perawat harus memberikan dorongan untuk pengungkapan serta harus mendengarkan, memahami, memberikan informasi yang bisa membantu menyingkirkan kekhawatiran ataupun kecemasan tersebut. Salah satunya dengan melakukan konseling. Konseling dianggap mampu menurunkan kecemasan pasien. Konseling dalam bentuk penyuluhan pre op ORIF akan mengurangi rasa takut akibat ketidaktahuan yang dialami pasien pre op ORIF (Muttaqin dan Sari, 2009). Berdasarkan data di atas, peneliti tertarik untuk meneliti bagaimanakah efek Kecemasan terhadap Peningkatan Tekanan Darah Pre Op ORIF.

\section{Metode Penelitian}

Penelitian ini merupakan penelitian deskriptif analitik dengan menggunakan pendekatan cros sectional. Populasi dari penelitian ini adalah pasien pre op ORIF di Ruang Flamboyan RSUD Gambiran Kota Kediri pada bulan Juli 2015. Pengambilan sampel dilakukan dengan purposive sampling. Dan akhirnya didapatkan 6 responden dengan kriteria:

1) Pasien yang akan menjalani operasi ORIF.

2) Pasien yang sadar (GCS 4-5-6).

3) Pasien yang tidak mengalami nyeri berat.

4) Pasien yang tidak gelisah.

5) Pasien yang tidak memiliki penyakit hipertensi.

6) Pasien yang bersedia menjadi responden.

Analisa yang digunakan untuk mengetahui efek kecemasan terhadap peningkatan tekanan darah digunakan analisis deskriptif dengan menggunakan diagram batang.

\section{Hasil penelitian}

Identifikasi Tingkat Kecemasan

Tabel 1 Distribusi Frekuensi Tingkat Kecemasan Pasien Pre Op ORIF yang di Rawat di Ruang Flamboyan RSUD Gambiran Kota Kediri pada tanggal 27-29 Juli 2015

\begin{tabular}{ccc}
\hline Tingkat & Frekuensi & Prosentase \\
\hline Kecemasan & 0 & $0 \%$ \\
$\begin{array}{c}\text { Tidak Ada } \\
\text { Kecemasan } \\
\text { Recemasan } \\
\text { Ringan } \\
\text { Kecemasan } \\
\text { Sedang } \\
\text { Kecemasan Berat }\end{array}$ & 2 & $33,3 \%$ \\
Panik & 3 & $16,7 \%$ \\
\hline Jumlah & 0 & $0 \%, 0 \%$ \\
\hline
\end{tabular}

Sumber : Data Penelitian (2015)

Tabel 1 menunjukkan bahwa dari 6 responden setengahnya 3 orang (50\%) mengalami Kecemasan Berat. 


\section{Identifikasi Tekanan Darah}

Tabel 2 Distribusi Frekuensi Tekanan Darah Sistole Pasien Pre Op ORIF yang di Rawat di Ruang Flamboyan RSUD Gambiran Kota Kediri pada tanggal 27-29 Juli 2015

\begin{tabular}{ccc}
\hline $\begin{array}{c}\text { Tekanan Darah } \\
\text { Sistole (mmHg) }\end{array}$ & Frekuensi & Prosentase \\
\hline$<120$ & 1 & $16,7 \%$ \\
$120-139$ & 1 & $16,7 \%$ \\
$140-159$ & 2 & $33,3 \%$ \\
$\geq 160$ & 2 & $33,3 \%$ \\
\hline Jumlah & 6 & $100 \%$ \\
\hline
\end{tabular}

Sumber : Data Penelitian (2015)

Tabel 2 menunjukkan bahwa dari 6 responden hampir sebagian masing masing 2 orang (33\%) memiliki tekanan darah Sistole 140-159 atau $\geq 160 \mathrm{mmHg}$.

Tabel 3 Distribusi Frekuensi Tekanan Darah Diastole Pasien Pre Op ORIF yang di Rawat di Ruang Flamboyan RSUD Gambiran Kota Kediri pada tanggal 27-29 Juli 2015

Tekanan Darah $\quad$ Frekuensi Prosentase

$\begin{array}{ccc}<80 & 0 & 0 \% \\ 80-89 & 1 & 16,7 \% \\ 90-99 & 4 & 66,6 \% \\ \geq 100 & 1 & 16,7 \% \\ \text { Jumlah } & 6 & 100 \%\end{array}$

Sumber : Data Penelitian (2015)

Tabel 3 menunjukkan bahwa dari 6 responden hampir sebagian besar 4 orang $(66,6 \%)$ memiliki tekanan darah Diastole 90-99 $\mathrm{mmHg}$.

\section{Analisa Efek Kecemasan terhadap Peningkatan Tekanan Darah Pasien Pre Op ORIF}

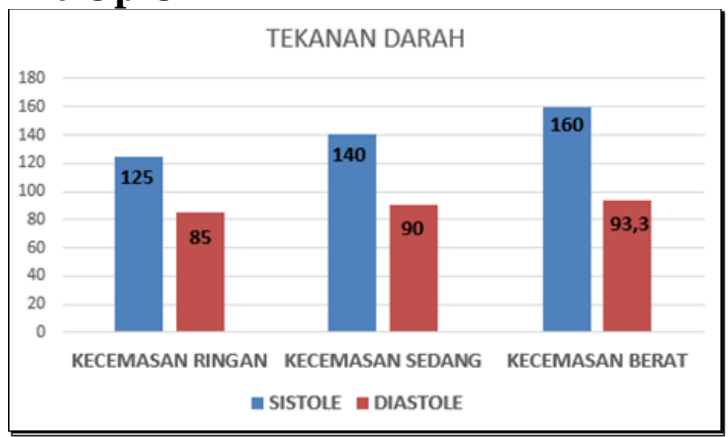

Gambar 1 Efek Kecemasan terhadap Peningkatan Tekanan Darah Sistole Pre Op ORIF yang di Rawat di Ruang Flamboyan RSUD Gambiran Kota Kediri pada tanggal 27-29 Juli 2015

Dari Gambar 1 semakin tinggi skor tingkat kecemasan, semakin meningkat pula tekanan darah Sistole dan Diastolenya.

\section{Pembahasan}

\section{Tingkat Kecemasan Pasien Pre Op} ORIF

Kecemasan merupakan keadaan ketika individu/kelompok mengalami perasaan gelisah (penilaian dan opini) dan aktivasi sistem saraf autonom dalam berespons terhadap ancaman yang tidak jelas, nonspesifik (Carpenito, 2006). Kecemasan merupakan suatu keadaan emosi tanpa suatu objek yang spesifik dan pengalaman subjektif dari individu serta dan tidak dapat diobservasi dan dilihat secara langsung (Sari, 2013). Persiapan mental merupakan hal yang tidak kalah pentingnya dalam proses persiapan operasi karena mental pasien yang tidak siap atau labil dapat berpengaruh terhadap kondisi fisiknya. Masalah mental yang biasa muncul pada pasien preoperasi adalah kecemasan (Smeltzer, 2002).

Sesuai dengan uraian di atas, kondisi kecemasan responden masing-masing berbeda. Kecemasan seseorang timbul akibat reaksi psikologis individu. Kecemasan dapat pula ditimbulkan akibat reaksi otomatis dari tubuh akibat stimulus internal dan eksternal yang berlebihan 
selain itu karena pembedahan ORIF yang ditunggu pelaksanaannya akan menyebabkan rasa takut dan cemas pada pasien yang menghubungkan pembedahan ORIF dengan rasa nyeri, kemungkinan cacat dan bergantung pada orang lain. Kecemasan tersebut dipengaruhi oleh beberapa faktor diantaranya umur, tingkat pendidikan dan pekerjaan.

Tahapan usia merupakan salah satu faktor presipitasi internal yang mempengaruhi kecemasan, dimana usia muda lebih cemas dibandingkan dengan individu usia lebih tua (Stuart, 2007). Semakin cukup umur seseorang, semakin baik psikologisnya dan semakin cukup umur seseorang maka semakin banyak pula pengalaman yang didapatnya.

Tingkat pendidikan seseorang atau individu akan berpengaruh terhadap kemampuan berfikir, semakin tinggi tingkat pendidikan akan semakin mudah berfikir rasional dan menangkap informasi baru termasuk dalam menguraikan masalah baru (Pamungkas Gunawan, 2001). Tingkat pendidikan yang lebih tinggi memiliki respon adaptasi yang lebih baik karena respon yang diberikan lebih rasional dan juga mempengaruhi kesadaran dan pemahaman terhadap stimulus (Notoadmodjo, 2003). Uraian di atas menunjukkan bahwa tingkat pendidikan individu berpengaruh terhadap kemampuan berpikir seseorang. Semakin tinggi pendidikan seseorang maka seseorang itu mampu menangani dan mengurangi kecemasan pada saat kondisikondisi tertentu khususnya pada saat akan menjalani operasi ORIF karena ketakutannya pada hal-hal yang tidak diinginkannya dan sebaliknya.

\section{Tekanan Darah Pre Op ORIF}

Tekanan darah dipengaruhi oleh beberapa faktor salah satunya adalah jenis kelamin.

Hasil penelitian menunjukkan bahwa dari 6 responden setengahnya 3 orang wanita pre op ORIF hampir sebagian masing-masing 2 orang (33\%) memiliki tekanan darah Sistole 140-159 $\mathrm{mmHg}$ (Hipertensi Stadium 1) atau $\geq 160 \mathrm{mmHg}$ (Hipertensi Stadium 2) dan sebagian besar 4 orang $(66,6 \%)$ tekanan darah diastole 90-99 mmHg (Hipertensi Stadium 1) atau $\geq 100 \mathrm{mmHg}$ (hipertensi stadium 2). Berdasarkan Journal of Clinical Hypertension, Oparil menyatakan bahwa perubahan hormonal yang sering terjadi pada wanita menyebabkan wanita lebih cenderung memiliki tekanan darah tinggi (Kozier, at al, 2009). Hasil pandangan peneliti bahwa seorang perempuan lebih cenderung memiliki tekanan darah tinggi dari pada laki-laki karena faktor fisik dalam kardiovaskuler dan psikologi yang membuat perempuan sangat sensitif terhadap sesuatu yang dihadapinya, disisi lain tanggung jawab perempuan dalam keluarganya menjadi sangat besar dibuktikan dari tidak sedikitnya perempuan berkarier sendiri dan juga tuntutan dari seorang suami yang membuat seorang perempuan rentan mengalami stres. Stres tersebut dapat meningkatkan tekanan darah.

Hasil dari penelitian hampir sebagian masing-masing 2 orang (33\%) memiliki tekanan darah Sistole 140-159 $\mathrm{mmHg}$ (Hipertensi Stadium 1) atau $\geq 160 \mathrm{mmHg}$ (Hipertensi Stadium 2) dan sebagian besar 4 orang $(66,6 \%)$ tekanan darah Diastole 90-99 mmHg (Hipertensi Stadium 1) dan sebagian kecil 1 orang $(16,7 \%) \geq 100$ mmHg (Hipertensi Stadium 2). Tekanan darah pada pasien yang akan menjalani operasi cenderung meningkat dikarenakan mengalami stres fisik (Smeltzer, 2002). Pasien yang akan menjalani operasi ORIF tekanan darah Sistole dan Diastolenya terletak pada Hipertensi Stadium 1 dan 2

\section{Efek Kecemasan Terhadap Peningkatan Tekanan Darah Pre Op ORIF pada Pasien Fraktur}

Kecemasan dan stres dapat menyebabkan stimulasi sistem saraf simpatis, yang meningkatkan frekuensi darah, curah jantung dan tahanan vaskular perifer. Efek simpatik meningkatkan 
tekanan darah selain itu juga stres atau ketegangan jiwa (rasa tertekan, murung, bingung, cemas, berdebar-debar, rasa marah, dendam, rasa takut, rasa bersalah) dapat merangsang kelenjar anak ginjal melepaskan hormon adrenalin dan memacu jantung berdenyut lebih cepat serta lebih kuat, sehingga tekanan darah akan meningkat. Jika stres berlangsung cukup lama, tubuh berusaha mengadakan penyesuaian sehingga timbul kelainan organis atau perubahan patologis (Kozier, at al, 2009).

Kecemasan pre Op ORIF memiliki Sifat Subyektif, dan sadar perasaan tentang kecemasan serta ketegangan yang disertai perangsangan sistem saraf otonom yang dapat menyebabkan peningkatan tekanan darah, karena pembedahan yang ditunggu pelaksanaannya akan menyebabkan rasa takut dan cemas pada pasien yang menghubungkan pembedahan dengan rasa nyeri, kemungkinan cacat, bergantung pada orang lain, sehingga timbul pikiran-pikiran negatif yang belum tentu akan terjadi. Rangsangan syaraf simpatis akan menyebabkan vasokonstriksi perifer yang akhirnya akan menimbulkan terjadinya retensi perifer. Retensi perifer ini akhirnya meningkatkan tekanan darah pasien pre op ORIF.

\section{Kesimpulan}

1. Kurangnya informasi tentang prosedur pembedahan yang akan dijalaninya akan meningkatkan kecemasan seseorang.

2. Semakin meningkat kecemasan seseoarang maka akan menyebabkan peningkatan tekanan sistole dan diastole

\section{Saran}

Kepada perawat atau dokter diharapkan memberikan penjelasan tentang prosedur dan tujuan operasi secara sederhana dengan bahasa yang mudah dipahami klien. Diharapkan untuk menurunkan kecemasan pada pasien pre op orif dengan berbagai tehnik relaksasi dan distraksi.

\section{Daftar Pustaka}

Arifah, S. dan Trise, I.N. (2012). Pengaruh Pemberian Informasi tentang Persiapan Operasi dengan Pendekatan Komunikasi Terapeutik terhadap Tingkat Kecemasan Pasien Pre Operasi. Jurnal Kebidanan

Badan Intelijen Negara, RI. (2013). Kecelakaan Lalu Lintas Menjadi Pembunuh Terbesar Ketiga. http://www.bin.go.id (di unduh tgl 28 Desember 2014, jam 16.00)

Carpenito, L. J. (2006). Buku Saku Diagnosa Keperawatan Edisi 10. Jakarta: EGC

Depkes RI. (2009). Jurnal Keperawatan. http://digilib.unimus.ac.id (di unduh tanggal 27 Desember 2014, jam 18.15 WIB)

Hasan, Iqbal. (2006). Analisa Data Penelitian dengan Statistik. Jakarta: Bumi Aksara

Kozier, et al. (2009). Buku Ajar Praktik Keperawatan Klinis Edisi 5. Jakarta: EGC

Muttaqin, Arif. (2008). Buku Ajar Asuhan Keperawatan Klien Gangguan Sistem Muskuloskeletal. Jakarta: EGC

Muttaqin, A. \& Sari, K. (2009). Asuhan Keperawatan Perioperatif: Konsep, Proses, dan Aplikasi. Jakarta: Salemba Medika

Notoatmodjo, S. (2003). Pendidikan dan Perilaku Kesehatan. Jakarta: Rineka Cipta.

Nurianah, Vivi. (2013). Ansietas (Cemas) pada Pre Operasi Kasus Fraktur Radius Ulna 1/3 Proximal Dextra. Program Diploma III Keperawatan Akademi Keperawatan Dharma Husada Kediri

Pamungkas, Gunawan. (2001). Konsep Kecemasan. http://teorikecemasan.com (diunduh 
tanggal 30 Juli 2015, jam 10.30 WIB)

Riyadi, S. \& Purwanto, T. (2009). Asuhan Keperawatan Jiwa. Yogyakarta: Graha Ilmu

Sari, J. N. (2013). Pengaruh Dzikir terhadap Penurunan Tingkat Kecemasan Pasien Pre Operatif Kanker Serviks di RSUD Dr. Pirngadi Medan. http://repository.usu.ac.id (di unduh tanggal 28 Desember 2014, jam 16.20 WIB)

Smeltzer, Suzanne C. Dan Bare. Brenda, G. (2002). Buku Ajar Keperawatan Medikal Bedah Brunner \& Suddarth (Edisi 8) Alih Bahasa oleh Agung Waluyo dkk. Jakarta: EGC

Stuart, Gail. W. (2007). Buku Saku Keperawatan Jiwa (Edisi 5). Jakarta: EGC 